\title{
Carcass and meat quality of Karacabey Merino and Kivircik lambs under an intensive finishing system
}

\author{
B. Ekiz ${ }^{1 \#}$, H. Atalay ${ }^{2}$, P.D. Akin ${ }^{1}$, N. Ozturk ${ }^{1}$, M. Birkiye ${ }^{3}$ \& A. Yilmaz ${ }^{1}$ \\ ${ }^{1}$ Istanbul University-Cerrahpasa, Faculty of Veterinary Medicine, Department of Animal Breeding and Husbandry, \\ Avcilar, 34320, Istanbul, Turkey \\ ${ }^{2}$ Balikesir University, Faculty of Veterinary Medicine, Department of Animal Nutrition and Nutritional Diseases, \\ Balikesir, Turkey \\ ${ }^{3}$ Balikesir Sheep and Goat Breeders Association, Balikesir, Turkey
}

(Received 9 October 2018; Accepted 5 September 2019; First published online 1 October 2109)
Copyright resides with the authors in terms of the Creative Commons Attribution 4.0 South African Licence.
See: http://creativecommons.org/licenses/by/4.0/za
Condition of use: The user may copy, distribute, transmit and adapt the work, but must recognise the authors and the South African Journal of Animal Science.

\begin{abstract}
Carcass and meat quality traits of male and female lambs are important considerations in planning gender-based production and developing a marketing strategy for the product. Thus, the aim of this study was to determine the effects of sex on carcass and meat quality of Kivircik and Karacabey Merino lambs. Twenty male and 17 female lambs were used. Lambs were weaned at 45 days old and then fed ad libitum with concentrates and roughage until slaughter at 120 days. The study was carried out in two experiments at three-month intervals. Kivircik lambs had greater dressing percentage $(47.96 \%$ vs $46.49 \%, P<0.05)$ and omental-mesenteric fat proportion $(1.71 \%$ vs $1.10 \%, P<0.01)$, while Karacabey Merino lambs had a greater proportion of skin $(11.14 \%$ vs $9.42 \%, P=0.001)$. Breed had no influence on water-holding capacity, shear force, $L^{*}$ and hue values $(P>0.05)$. The meat of Karacabey Merino lambs had greater $\mathrm{a}^{*}, \mathrm{~b}^{*}$ and chroma values after blooming for 24 hours than meat from Kivircik lambs. Male lambs had greater proportions of head $(5.39 \%$ vs $4.62 \%, P<0.001)$, feet $(2.65 \%$ vs $2.46 \%, P<0.01)$ and visceral organs $(4.53 \%$ vs $4.15 \%, P$ $<0.05)$, while females had a greater proportion of visceral fat $(1.76 \%$ vs $1.05 \%, P=0.001)$. Meat from female lambs was darker than meat from male lambs. In conclusion, under intensive conditions, the indigenous Kivircik breed had similar carcass and meat quality characteristics to the Karacabey Merino, a wool and meat breed.
\end{abstract}

Keywords: breed effect; carcass quality; sex; lamb; meat quality

\#Corresponding author: bekiz@istanbul.edu.tr

\section{Introduction}

Sheep and goats that are farmed in Turkey are generally low-yielding indigenous breeds under traditional management and feeding practices. In traditional breeding systems, the nutritional needs of the animals are not met properly because of grazing low-quality grasslands. This generally results in low production, and farmers are not able to earn a decent income (Ekiz et al., 2013). On the other hand, demand for animal-based protein has increased in Turkey, parallel with the growth in population. Owing to domestic production being insufficient to meet demand, the importation of meat has become necessary. This situation indicates that meat production needs to increase. Semi-intensive and intensive sheep production systems should be considered, in which the management and nutritional needs of the animals are optimized. In this context, the number of intensive fattening enterprises has started to increase in the recent years, with lambs being fed concentrate-based diets from weaning until they reach slaughter weight (Ekiz et al., 2012).

Since increased carcass weight is one of the most important targets of the intensive fattening systems, meat-type breeds are usually preferred to indigenous ones. This situation poses a risk of extinction for many indigenous breeds, which are nonetheless well adapted to low quality diets and harsh environmental conditions. Meat from lambs of certain indigenous breeds that are reared in traditional production systems may be viewed as unique, and is consumed with appreciation by consumers around the world (Fisher et al., 
2000). The determination of carcass and meat quality characteristics of lambs from indigenous breeds under intensive fattening systems may contribute to their protection, if they have acceptable meat quality.

Kivircik is an indigenous breed of Marmara Region of Turkey and is also raised in Balkan countries such as Bulgaria and Greece. It is noted for its meat quality and distinguished by its thin tail (Yilmaz et al., 2009). Over the last 20 years, the number of Kivircik sheep has decreased rapidly owing to uncontrolled crossbreeding. On the other hand, Karacabey Merino is a dual-purpose breed that is used for wool and meat (Yalcin, 1986). Karacabey Merino was developed in a crossbreeding study. It is composed of approximately 95\% of German Mutton Merino and 5\% of Kivircik germplasm (Yalcin, 1986). Some research has been conducted to investigate the carcass characteristics of these breeds (Ekiz \& Altinel, 2005; Ekiz et al., 2009). However, few studies have investigated the meat quality characteristics of lambs from these breeds under intensive finishing.

To produce desirable carcasses and meat, breed choice needs to be done properly. There may also be an effect of sex of lamb on the carcass and meat quality traits, especially fatness (Sañudo et al., 1998; Santos et al., 2015). Knowing the carcass and meat quality traits of male and female lambs would be important for planning gender-based production systems and developing appropriate marketing strategies. The aim of this study was to determine the effects of sex and breed on carcass and meat quality traits of lambs that are representative of the Kivircik and Karacabey Merino breeds that are managed under an intensive fattening programme.

\section{Materials and Methods}

The experimental procedures used in this study were approved by the Ethic Committee of Istanbul University (Approval No: 2016/25).

The experiment was conducted at Balikesir University Veterinary Faculty Experimental Sheep Farm in 2016. Twenty males and 17 females from the Kivircik and Karacabey Merino breeds were evaluated. The study was conducted in two replicates that were separated in time by three months.

The flock from which the evaluated lambs originated had a total of 240 head of Kivircik and 200 head of Karacabey Merino ewes. For breeding, 10 Kivircik and 8 Karacabey Merino rams were joined with the ewes of their own breeds. As a result, 210 Kivircik and 190 Karacabey Merino lambs were born. In late pregnancy, the ewes were penned in groups of 10 for lambing. When the lambs were born, they stayed in these pens and with their dams for seven days, after which time the lambs were placed in another pen. From one week old onwards, the lambs were allowed to nurse twice a day, in the morning and evening. Concentrate pelleted feed of $3.5 \mathrm{~mm}$ was supplied to the lambs after the age of one week, and roughage (chopped 8-10 cm) was introduced at 15 days old. Lambs were weaned at an average age of 45 days when they were put into fattening pens $\left(2.5 \mathrm{~m}^{2}\right.$ for each lamb) according to their breed, sex and live weight. Within a replicate, the weaned lambs of the two breeds were finished together. The lambs were fed concentrate and roughage ad libitum until they were slaughtered. The chemical compositions of concentrate and alfalfa hay are presented in Table 1.

Table 1 Chemical composition of concentrate feed and alfalfa hay as percentage of dry matter for all items except dry matter and metabolizable energy

\begin{tabular}{|c|c|c|}
\hline Chemical composition ${ }^{1}$ & Concentrate feed & Alfalfa hay \\
\hline Dry matter, \% & 87.9 & 86.4 \\
\hline Crude protein, $\%$ & 16.85 & 16.23 \\
\hline Ether extract, \% & 4.51 & 2.72 \\
\hline Crude cellulose, \% & 6.44 & 25.4 \\
\hline Ash, \% & 6.51 & 8.66 \\
\hline NDF, $\%$ & 24.65 & 46.33 \\
\hline$A D F, \%$ & 9.86 & 34.68 \\
\hline Metabolizable energy ${ }^{2},(\mathrm{MJ} \mathrm{ME} / \mathrm{kg} \mathrm{DM})$ & 11.27 & 8.76 \\
\hline
\end{tabular}

${ }^{1}$ NDF: neutral detergent fibre, ADF acid detergent fibre

${ }^{2}$ Calculated values 
The lamb market in the region desires lambs with carcass weight less than $20 \mathrm{~kg}$. Therefore, the lambs were sent to slaughter when they were four months old. Initially, five female and five male lambs from each breed were to be slaughtered when they reached an average of 122 days (min 108 days, max 136 days). However, the number of females that were available from the Karacabey Merino breed was less than planned because of competing needs for these animals. Thus, four female Karacabey Merino lambs were slaughtered in the first replicate and three female lambs in the second (Table 2). All of the lambs in the study were randomly selected from healthy lambs in the flock. The mean age and weight of these lambs reflected the mean values for their breed and sex subgroups. The lambs in the first replicate were slaughtered in the last week of March, and the lambs in the second replicate were slaughtered in the last week of June.

Table 2 Numbers of male and female lambs within each breed and within each replicate

\begin{tabular}{lccccc}
\hline \multirow{2}{*}{ Sex } & \multicolumn{2}{c}{ Kivircik $(\mathrm{n}=20)$} & & \multicolumn{2}{c}{ Karacabey Merino $(\mathrm{n}=17)$} \\
\cline { 2 - 3 } & First replicate $(\mathrm{n}=10)$ & Second replicate $(\mathrm{n}=10)$ & & First replicate $(\mathrm{n}=9)$ & Second replicate $(\mathrm{n}=8)$ \\
\hline \multirow{2}{*}{ Male } & 5 & 5 & 5 & 5 & 3 \\
Female & 5 & 5 & & 4 & 5 \\
\hline
\end{tabular}

Lambs were slaughtered in the same abattoir with the same procedures for both replicates. Preslaughter live weights of the lambs were recorded immediately before slaughter. Hot carcass weight and weights of non-carcass components such as head, feet, skin, visceral organs (liver, lung, trachea, heart and spleen), and visceral fat removed from the omenta and mesentery fat were recorded shortly after slaughter. The carcasses were numbered, placed in a cold storage room and chilled at $4{ }^{\circ} \mathrm{C}$ for 24 hours. Back fat thickness was measured at the section between the last thoracic and first lumbar vertebrae, and $3 \mathrm{~cm}$ off the dorsal midline by a digital calliper. Backfat colour was measured on the layer of fat over the left $M$. longissimus thoracis, aligned with the 12th to 13th thoracic vertebrae. To determine carcass conformation and fatness scores, three people from the research team compared photographs of the carcasses that were taken at the abattoir with the photographic standards of the EUROP system (Ruiz de Huidobro et al., 2003).

For the analysis of meat quality, 8-10 cm length and 3-4 cm width muscle samples were taken from the left side of Longissimus thoracis (LT) muscle at 24 hours post mortem. These samples were further aged for $72 \mathrm{~h}$ at $4{ }^{\circ} \mathrm{C}$. After ageing, 3-4 cm and 5-6 cm (30 g) meat samples were taken from the LT muscle to determine expressed juice, colour, and Warner-Bratzler (WB) shear force, respectively.

To determine expressed juice, a modification of the Grau and Hamm method was applied (Beriain et al., 2000). For colour measurements, 2-cm thick cross-sections were taken from each meat sample and placed on plates with the cut surface facing upwards. Two assessments were made of these samples after one hour and 24 hours' blooming, while they were kept at $4{ }^{\circ} \mathrm{C}$ under continuous white light $(750 \mathrm{Ix})$. To determine meat colour parameters, a chromometer that measures with the $L^{*}, a^{*}$, and $b^{*}$ coordinate system was used (Minolta CR 400, Minolta Camera Co., Osaka, Japan). The standards of Commission Internationale de L'Éclairage (CIE, 1976) were applied for the measurements. Aperture size was $8 \mathrm{~mm}$, observation angle was $2^{\circ}$, and D65 was chosen as the light source. Immediately before the measurements, the device was calibrated with a white calibration plate $(Y=93.8, x=0.316, y=0.3323)$. Colour measurements were done from a fat-free area of the cut surface. Nine measurements were recorded for each sample and colour coordinate value was determined by calculating the average of these nine measurements. Meat chroma and hue angle were calculated by using $\mathrm{a}^{\star}$ component from green (-) to red $(+)$, and $b^{*}$ component from blue $(-)$ to yellow $(+)$ coordinate values as given below (Murray, 1995):

$$
\text { Chroma }=\left[\left(a^{\star}\right)^{2}+\left(b^{\star}\right)^{2}\right]^{0.5} \quad \text { Hue angle }=\tan ^{-1}\left(b^{\star} / a^{\star}\right)
$$

To determine cooking loss and shear force, meat samples $(5-6 \mathrm{~cm}$ in length and $59.3 \pm 1.89 \mathrm{~g})$ from the LT muscle were weighed, vacuum packed and cooked at $80^{\circ} \mathrm{C}$ for 45 minutes in a water bath. After cooking, the samples were taken out of the water bath and cooled under tap water for 60 minutes. After being cooled, the meat samples were removed from the vacuum packages, dried with paper towels, and reweighed to determine their final weight after the cooking process. Cooking loss was determined as the ratio (\%) of weight difference between initial weight and cooked weight to initial weight (Honikel, 1998). These same samples were used to determine the WB shear force. Four to six cores $1 \times 1 \mathrm{~cm}$ thick and 2.5 
to $3 \mathrm{~cm}$ in length were cut parallel to the muscle fibres from each sample. The WB blade for the Instron test device (model 3343, Instron Corp., Norwood, MA, USA), was used for this analysis with the force applied to the meat adjusted to $50 \mathrm{~kg}$ and the blade speed set at $200 \mathrm{~mm} / \mathrm{min}$.

Before the statistical comparisons, normal distribution of the data was tested by applying Shapiro-Wilk test in SPSS 13.0 programme package (SPSS Inc, Chicago, Illinois, USA) and the data were found to be normally distributed. Therefore, the raw data (untransformed data) were analysed. The GLM procedure in SPSS 13.0 program was used to assess effects of breed and sex of lamb on the carcass and meat quality characteristics. The linear model also included replicate as a fixed effect and slaughter age as a covariate. Mathematically the model can be described as:

$$
\gamma_{i j k l}=\mu+a_{i}+\mathrm{c}_{j}+a \mathrm{c}_{i j}+\mathrm{d}_{k}+b\left(\mathrm{X}_{i j k l}-\overline{\mathrm{X}}\right)+e_{i j k l}
$$

Where: $\gamma_{i j k l}$ is an observation from a lamb of the ith breed (Kivircik or Karacabey Merino) and jth sex (male or female) that was produced in the kth replicate. In this model

$\mu=$ the general mean

$a \mathrm{c}_{i j}$ designates the interaction of breed and sex

$b=$ average linear effect age at slaughter when the Ith lamb was $\mathbf{X}_{i j k l}$ days old

If the effect of age and its interaction with breed were not significant, the data were re-analysed with these effects removed from the model.

\section{Results and Discussion}

Means of breed and sex of the lambs on average daily gain (ADG) and slaughter characteristics are given in Table 3.

Table 3 Least squares means (SD) for slaughter characteristics of lambs according to breed and sex

\begin{tabular}{|c|c|c|c|c|c|c|c|}
\hline \multirow[b]{2}{*}{ Characteristics } & \multicolumn{2}{|c|}{ Breed (B) } & \multicolumn{2}{|c|}{$\operatorname{Sex}(S)$} & \multicolumn{3}{|c|}{$P$-Values } \\
\hline & $\begin{array}{l}\text { Kivircik } \\
(n=20)\end{array}$ & $\begin{array}{c}\text { Merino } \\
(\mathrm{n}=17)\end{array}$ & $\begin{array}{c}\text { Male } \\
(n=20)\end{array}$ & $\begin{array}{l}\text { Female } \\
(n=17)\end{array}$ & B & $S$ & $B \times S$ \\
\hline $\mathrm{ADG}^{1}, \mathrm{~g}$ & $288.3(21.2)$ & $296.0(21.8)$ & $300.0(21.3)$ & $284.3(21.4)$ & 0.294 & 0.034 & 0.513 \\
\hline Slaughter age, days & $123.6(9.1)$ & $119.45(9.4)$ & $118.7(9.2)$ & $124.3(9.2)$ & 0.186 & 0.075 & 0.835 \\
\hline Preslaughter weight, kg & $39.51(2.46)$ & $39.13(2.56)$ & $39.87(2.55)$ & $38.76(2.52)$ & 0.653 & 0.207 & 0.533 \\
\hline Hot carcass weight, $\mathrm{kg}$ & 18.99 (1.39) & $18.14(1.44)$ & $18.61(1.43)$ & $18.52(1.44)$ & 0.087 & 0.858 & 0.959 \\
\hline Dressing percentage, \% & $47.96(1.65)$ & $46.49(1.73)$ & $46.82(1.70)$ & $47.62(1.69)$ & 0.013 & 0.158 & 0.251 \\
\hline Head proportion, \% & $4.90(0.30)$ & $5.10(0.31)$ & $5.39(0.30)$ & $4.62(0.31)$ & 0.053 & $<0.001$ & $<0.001$ \\
\hline Male & $5.48^{\mathrm{a}}(0.42)$ & $5.27^{\mathrm{a}}(0.40)$ & & & & & \\
\hline Female & $4.37^{\mathrm{c}}(0.42)$ & $4.92^{\mathrm{b}}(0.47)$ & & & & & \\
\hline Feet, \% & $2.50(0.17)$ & $2.60(0.17)$ & $2.65(1.17)$ & $2.46(0.17)$ & 0.096 & 0.002 & 0.397 \\
\hline Skin, \% & $9.42(1.43)$ & $11.14(1.48)$ & $9.92(1.44)$ & $10.65(1.45)$ & 0.001 & 0.137 & 0.803 \\
\hline Visceral organs, \% & $4.47(0.55)$ & $4.20(0.57)$ & $4.53(0.55)$ & $4.15(0.56)$ & 0.159 & 0.047 & 0.190 \\
\hline Visceral fat, \% & $1.71(0.52)$ & $1.10(0.54)$ & $1.05(0.52)$ & $1.76(0.53)$ & 0.002 & 0.001 & 0.678 \\
\hline
\end{tabular}

${ }^{1} \mathrm{ADG}$ : average daily gain between birth and slaughter age [(preslaughter weight - birth weight) / slaughter age]

$a, b, c$ Means with different superscripts for $B \times S$ subgroups are significantly different

Kivircik and Karacabey Merino lambs had similar ADG values when they were reared, fed and housed in similar conditions under intensive breeding. The ADG value $(296 \mathrm{~g})$ of Karacabey Merino lambs in this study was found to be consistent with previous studies (Ozcan et al., 2005; Sezenler et al., 2013), yet the ADG value (288 g) of Kivircik lambs was greater than previously observed (195-225 g) (Ekiz \& Altinel, 2005; Ekiz et al., 2013). The lack of significant differences in ADG between the breeds indicated that Kivircik lambs may have similar potential for meat production to Karacabey Merino lambs, if the lambs were finished under an intensive fattening programme with free access to concentrates. 
Differences between Kivircik and Karacabey Merino lambs in slaughter age, preslaughter weight, hot carcass weight and head, feet and visceral organs proportions were not significant $(P>0.05)$. The skin proportion of Karacabey Merino lambs was greater than that of Kivircik lambs $(P<0.01)$. The wool yield of Karacabey Merino was $3.6 \mathrm{~kg}$ versus $1.5 \mathrm{~kg}$ for Kirvicik (Anonymous, 2009). Thus, it was anticipated that Karacabey Merino lambs, which were developed for their wool and meat yields, would have a greater proportion of skin than Kivircik lambs. Many researchers reported that Turkish Merino lambs had a greater proportion of skin than Kivircik lambs (Karabacak, 2007; Yilmaz et al., 2009). Dressing percentage of Karacabey Merino lambs was less for Kivircik lambs $(P<0.05)$. The greater proportion of skin, as a noncarcass component, in Karacabey Merino lambs may explain their lower dressing percentage. Dressing percentages observed in this study $(47.96 \%$ for Kivircik, $46.49 \%$ for Karacabey Merino lambs) were consistent with previous studies (Altinel et al., 1998; Yilmaz et al., 2002; Karabacak \& Boztepe, 2008; Yilmaz et al., 2009; Ekiz et al., 2013).

In the current study, Kivircik lambs had a greater proportion of visceral fat than Karacabey Merino lambs $(P<0.01)$. This may be because Karacabey Merino is a meat-wool type breed that was developed for meat production in Turkey. Yilmaz et al. (2009) also reported that when Kivircik lambs had ad libitum access to concentrate feed, they tended to have a greater percentage of visceral fat than Turkish Merino lambs.

The sex effect was significant for proportions of feet $(P<0.01)$, visceral organs $(P<0.05)$ and visceral fat proportions $(P<0.01)$ and differed by breed for head as a percentage of carcass weight $(P<0.01)$. Head, feet and visceral organs percentages for male lambs were greater than for females. Male lambs also had greater ADG than females $(P<0.05)$. Previously, male lambs of the Kivircik and Karya breeds were found to have greater ADG, and percentages of head and feet than female lambs (Altin et al., 2005). Also similar to the current results, Pérez et al. (2007) reported that male lambs from four breed types had greater weights of head, feet, liver and spleen than their female counterparts. Koycu \& Ozder (2004) also found that male Turkgeldi genotype lambs had greater ADG, feet and visceral organ weights than female ones.

Shrinkage loss, conformation and fatness scores, back fat thickness and fat colour parameters were not affected by breed $(P>0.05$, Table 4$)$. Female lambs had a greater proportion of visceral fat $(P<0.01)$ and carcass fatness scores $(P<0.01)$ than male lambs. However, the sex effect on backfat thickness was not significant. Díaz et al. (2003) found female Manchego lambs were generally fatter than their male counterparts. Objective and subjective fatness scores may be related because, from an early age, females generally tend to deposit more fat than males (Díaz et al., 2003). They added that the significant effect of sex on fatness might be related to a difference between male and female lambs in their protein assimilation efficiency. The recognition of male lambs' greater potential for nitrogen retention and their tendency to develop more muscle tissue than adipose tissue may be a plausible explanation (Díaz et al., 2003). Koycu \& Ozder (2004) also found that female Turkgeldi lambs had a greater percentage of visceral fat than male lambs.

With the exceptions of pre-slaughter weight, hot carcass weight, back fat thickness and fat colour lightness, the effect of slaughter age was not significant. As expected, pre-slaughter weight, hot carcass weight and fat thickness all increased with increasing slaughter age. On the contrary, fat became darker in colour ( $L^{*}$ increased) as age at slaughter increased.

The least squares means for the meat quality characteristics are given in Table 5 . The differences between Kivircik and Karacabey Merino lambs in terms of expressed juice and cooking loss of LT muscles were not significant $(P>0.05)$. Many other researchers also reported that breed or genotype had no significant influence on expressed juiciness (Purchas et al., 2002; Silva Sobrino et al., 2003) and cooking loss (Hopkins \& Fogarty, 1998; Hoffman et al., 2003; Ekiz et al., 2009). Cooking losses that were observed in the present study were similar to those found by Ekiz et al. (2012) with older lambs.

Tenderness of cooked meat is an important determinant of consumer satisfaction. Meat tenderness may be affected by muscle protein, intramuscular fat proportion, structure of connective tissue, size of the muscle bands and water-holding capacity (Sañudo et al., 1998; Santos-Silva \& Portugal 2001). In the current study, Kivircik and Karacabey Merino lambs had WB shear force values that did not differ significantly. Shackelford et al. (1991) noted that meat samples that have WB shear force values greater than $5.5 \mathrm{~kg}$ $(53.94 \mathrm{~N})$, might be evaluated by panellists and consumers as being tough. Using this criterion, the meat of four Karacabey Merino lambs (23.5\%) and three Kivircik lambs' (15\%) may be regarded as being tough. 
Table 4 Least squares means (SD) for carcass characteristics of lambs according to breed and sex ${ }^{\mathrm{a}}$

\begin{tabular}{|c|c|c|c|c|c|c|c|}
\hline \multirow{2}{*}{ Characteristics } & \multicolumn{2}{|c|}{ Breed (B) } & \multicolumn{2}{|c|}{$\operatorname{Sex}(S)$} & \multicolumn{3}{|c|}{$P$-values } \\
\hline & Kivircik & Merino & Male & Female & B & S & $B \times S$ \\
\hline Shrinkage loss, $\%$ & $2.01(0.93)$ & $1.57(0.96)$ & $1.89(0.93)$ & $1.69(0.94)$ & 0.167 & 0.511 & 0.856 \\
\hline Conformation score ${ }^{\mathrm{b}}$ & $9.99(1.40)$ & $9.91(1.44)$ & $9.56(1.41)$ & $10.35(1.42)$ & 0.839 & 0.053 & 0.313 \\
\hline Fatness score ${ }^{b}$ & $10.12(1.37)$ & $9.59(1.41)$ & $9.32(1.38)$ & $10.38(1.39)$ & 0.125 & 0.003 & 0.199 \\
\hline Back fat thickness, mm & $8.27(0.24)$ & $7.84(2.52)$ & $8.00(0.25)$ & $8.11(2.47)$ & 0.592 & 0.889 & 0.723 \\
\hline \multicolumn{8}{|l|}{ Fat colour parameters } \\
\hline$L^{*}$ & $69.43(3.13)$ & $68.83(2.99)$ & $68.99(2.95)$ & $69.27(3.14)$ & 0.510 & 0.758 & 0.325 \\
\hline$a^{*}$ & $3.51(1.92)$ & $3.82(1.61)$ & $3.52(1.57)$ & $3.82(1.61)$ & 0.565 & 0.569 & 0.126 \\
\hline$b^{*}$ & $8.66(1.70)$ & $9.22(1.75)$ & $9.14(1.70)$ & $8.74(1.72)$ & 0.344 & 0.485 & 0.273 \\
\hline Chroma & $9.46(1.88)$ & $10.21(1.93)$ & $9.95(1.89)$ & $9.72(1.90)$ & 0.243 & 0.717 & 0.134 \\
\hline Hue angle & $67.54(7.65)$ & $66.72(7.88)$ & $68.23(7.69)$ & $66.03(1.88)$ & 0.754 & 0.396 & 0.391 \\
\hline
\end{tabular}

${ }^{a}$ Generalized linear model of variance (GLM ANOVA) was used for the statistical analyses

${ }^{\mathrm{b}}$ Conformation or fatness scores according to EUROP system with scales 1-15 (1 = lowest conformation or fatness; $15=$ best conformation or highest fatness)

Table 5 Least square means (SD) for meat quality characteristics measured from Longissimus thoracis muscles of lambs according to breed and sex $^{a}$

\begin{tabular}{|c|c|c|c|c|c|c|c|}
\hline \multirow{2}{*}{ Characteristics } & \multicolumn{2}{|c|}{ Breed (B) } & \multicolumn{2}{|c|}{$\operatorname{Sex}(\mathrm{S})$} & \multicolumn{3}{|c|}{$P$-Values } \\
\hline & Kivircik & Merino & Male & Female & B & $\mathrm{S}$ & $B \times S$ \\
\hline Expressed juice $^{\mathrm{b}}, \%$ & $10.49(1.79)$ & $10.55(1.86)$ & $10.28(1.82)$ & $10.76(1.81)$ & 0.92 & 0.43 & 0.31 \\
\hline Cooking loss, $\%$ & 24.89 (3.09) & $24.55(3.18)$ & $24.64(3.40)$ & $24.81(2.87)$ & 0.74 & 0.87 & 0.75 \\
\hline$W^{c}$ shear force, $N$ & $46.78(8.41)$ & $49.03(8.69)$ & $46.58(8.51)$ & $49.13(8.53)$ & 0.42 & 0.37 & 0.64 \\
\hline \multicolumn{8}{|c|}{ Colour measures after $1 \mathrm{~h}$ blooming } \\
\hline$L^{*}$ & $37.11(1.65)$ & 37.25 (1.69) & $38.07(1.65)$ & $36.30(1.67)$ & 0.81 & $<0.01$ & 0.93 \\
\hline$a^{*}$ & $17.58(1.29)$ & $18.30(1.33)$ & $17.16(1.30)$ & $18.71(1.31)$ & 0.11 & $<0.01$ & 0.37 \\
\hline$b^{*}$ & $3.52(1.14)$ & $4.16(1.18)$ & $3.70(1.15)$ & $3.98(1.16)$ & 0.11 & 0.47 & 0.62 \\
\hline Chroma & $17.93(1.41)$ & $18.80(1.45)$ & $17.59(1.42)$ & $19.15(1.43)$ & 0.08 & $<0.01$ & 0.41 \\
\hline Hue angle & $11.30(3.09)$ & $12.57(3.18)$ & $12.04(3.11)$ & $11.82(1.13)$ & 0.23 & 0.83 & 0.70 \\
\hline \multicolumn{8}{|c|}{ Colour measures after $24 \mathrm{~h}$ blooming } \\
\hline$L^{*}$ & $38.58(2.77)$ & $38.41(2.66)$ & $39.19(2.59)$ & $37.80(2.79)$ & 0.69 & $<0.01$ & 0.68 \\
\hline$a^{*}$ & $16.34(1.65)$ & $17.59(1.59)$ & $16.03(1.57)$ & $17.90(1.67)$ & 0.03 & $<0.01$ & 0.28 \\
\hline$b^{*}$ & $6.21(1.20)$ & $7.09(1.15)$ & $6.47(1.13)$ & $6.83(1.21)$ & $<0.01$ & 0.14 & 0.94 \\
\hline Chroma & $17.50(1.71)$ & $19.00(1.64)$ & $17.32(1.61)$ & $19.18(1.72)$ & 0.01 & $<0.01$ & 0.34 \\
\hline Hue angle & $20.80(3.65)$ & $22.08(3.50)$ & $21.90(3.44)$ & 20.98 (3.67) & 0.06 & 0.169 & 0.30 \\
\hline
\end{tabular}

\footnotetext{
${ }^{a}$ Generalized linear model of variance (GLM ANOVA) was used for the statistical analyses

b Ratio of weight loss of meat samples to its initial weight

'WB: Warner Bratzler
}

Meat colour is an important criterion that is used by customers to evaluate freshness and quality of meat during purchase (Priolo et al., 2001). When the colour parameters of LT muscle samples were measured after 1 hour blooming, the differences between Kivircik and Karacabey Merino lambs in lightness $\left(L^{*}\right), a^{*}$ (green (-) to red $\left.(+)\right), b^{*}$ (blue $(-)$ to yellow $(+)$ ), chroma, and hue angle were not significant. However, 
after 24 hours' blooming, $a^{\star}, b^{\star}$ and chroma values of the meat of Karacabey Merino lambs were greater than Kivircik ones. In a previous study with the same breeds, Ekiz et al. (2009) reported that differences between Kivircik and Merino lambs for $L^{*}$ and $b^{*}$ at all measurement times, and for $a^{*}$ values after 1 hour blooming were not significant. However, the authors found Kivircik lambs had greater $\mathrm{a}^{*}$ values after 24 hours' blooming than Merino lambs. Many studies conducted with various genotypes indicated significant breed effects on $a^{*}$ (Martínez-Cerezo et al., 2005; Burke \& Apple, 2007; Warner et al., 2007) and b* values (Teixeira et al., 2005). Warner et al. (2007) investigated differences among various crossbreds (Poll Dorset $\times$ Border Leicester, Poll Dorset $\times$ Merino, Merino $\times$ Merino and Border Leicester $\times$ Merino) and slaughter age $(8,14$, and 22 months) on the retail display life of $M$. longissimus thoracis and $M$. rectus femoris samples. They found LT muscle samples of Merino lambs were most susceptible to discoloration during retail display and least acceptable to consumers. Differences in $\mathrm{a}^{*}$ also result from differences in feed (Ponnampalam et al., 2014), slaughter age (Polidori et al., 2017) and pre-slaughter stress (Linares et al., 2007). However, in the present study the lambs were reared together, fed the same diet, and slaughtered at the same age, irrespective of breed.

Hopkins \& Nicholson (1999) reported that $L^{*}$ values of meat samples less than 34 were classified as dark coloured and were unacceptable to consumers. In this study no such samples were observed. Khliji et al. (2010) found that when $a^{*}$ values were equal to or greater than 9.5 , consumers evaluated these meats as acceptable. The meat from Kivircik lambs had $\mathrm{a}^{*}$ values between 13.4 and 20.7 , and the meat from Karacabey Merino lambs had $a^{*}$ values from 14.7 to 22.2 . Thus, based on the $L^{*}$ and $a^{*}$ values, the meat from both breeds is expected to be acceptable to consumers, based on their criteria for its colour.

Differences between male and female lambs in terms of expressed juice, cooking loss and WB shear force values were not significant $(P>0.05)$. The results of many studies indicated the similarity between sexes for expressed juice (Morbidini et al., 2001), cooking loss (Santos et al., 2007; Velasco et al., 2000; Santos et al., 2015) and WB shear force values (Velasco et al., 2000; Morbidini et al., 2001; Teixeira et al., 2005; Santos et al., 2007, 2015).

Differences between male and female lambs for $b^{*}$ and hue angle values were not significant. However, LT samples of female lambs had reduced $L^{*}$, and greater $a^{*}$ and chroma values than male lambs. Similar to the current results, Santos et al. (2015) reported that LT muscle samples of male Churra Glega Mirandesa lambs had greater $L^{*}$ values, while female lambs had higher $a^{*}$ values. Teixeira et al. (2005) reported that female lambs had lower $L^{*}$ values of $M$. longissimus dorsi samples than the male counterparts. Thompson et al. (1979) explained female lambs with darker meat at a similar slaughter weight might result from their being more precocious than male lambs. However, Horcada et al. (1998) and Tejeda et al. (2008) did not detect effects of sex on meat colour.

\section{Conclusion}

Under intensive finishing conditions, indigenous Kivircik lambs may have similar fattening performance to meat-type breeds. Given the similarity of Kivircik and Karacabey Merino lambs in carcass weight, backfat thickness, conformation score, fatness score, and water-holding capacity and shear force values of the meat, Kivircik lambs may be an option for producing quality lamb meat when fed ad libitum. The limited number of animals in each breed $x$ sex subclass is a limitation of this study. Further studies, with larger numbers of animals, seem warranted to compare carcass and meat quality of Kivircik and Karacabey Merino lambs under different production systems.

\section{Acknowledgements}

The researchers would like to thank the Sheep and Goat Breeders' Association of Balikesir Province for supplying the lambs that were used in this study and Bigadic Kose Slaughterhouse for the opportunity to use their slaughterhouse.

\section{Authors' Contributions}

$\mathrm{BE}$ and $\mathrm{HA}$ were in charge of the experimental design. $\mathrm{HA}$ and $\mathrm{MB}$ conducted the finishing and slaughtering parts of the study. BE, NO, PDA and AY analysed the meat samples. BE, HA and AY wrote the manuscript. All authors participated in interpreting and reviewing the results of the study.

\section{Conflict of Interest Declaration}

There are no conflicts of interest.

\section{References}

Altin, T., Karaca, O., Cemal, I., Yilmaz, M. \& Yilmaz, O., 2005. The fattening and carcass characteristics of Kivircik and Karya lambs. J. Anim. Prod. 46, 19-29.

Altinel, A., Evrim, M., Ozcan, M., Baspinar, H. \& Deligozoglu, F., 1998. Studies on possibility of producing high quality lambs by crossbreeding among Sakiz, Kivircik and German Black Headed mutton sheep. Turk. J. Vet. Anim. Sci. 22, 257-265. 
Anonymous 2009. Turkish Farm Animal Genetic Resources Catalogue. Republic of Turkey, Ministry of Food, Agriculture and Livestock. General Directorate of Agricultural Research and Policies. https://www.tarimorman.gov.tr/TAGEM/Belgeler/yayin/Katalog\%20T\%C3\%BCrk\%C3\%A7e.pdf

Beriain, M.J., Horcada, A., Purro, A., Lizaso, G., Chasco, J. \& Mendizabal, J.A., 2000. Characteristics of Lacha and Rasa Aragonesa lambs slaughtered at three live weights. J. Anim. Sci. 78, 3070-3077.

Burke, J.M. \& Apple, J.K., 2007. Growth performance and carcass traits of forage-fed hair sheep wethers. Small Rumin. Res. 67, 264-267.

CIE, 1976. Centre Internationale de L'Eclairage. Definition dun space de coleur por deux coordonees de cromaticité et la luminosite. Supplement 2 to CIE publication no 15 (E-1-3-1) 1971/(TC-1-3). Centre Internationale de L'Eclairage, Paris (in French).

Díaz, M.T., Velasco, S., Pérez, C., Lauzurica, S., Ruiz de Huidobro, F. \& Cañeque, V., 2003. Physico-chemical characteristics of carcass and meat Manchego-breed suckling lambs slaughtered at different weights. Meat Sci. $65,1085-1093$.

Ekiz, B. \& Altinel, A., 2005. The possibilities of using German Black Headed mutton genotypes to get high quality lambs from Kivircik ewes, II. Fattening, slaughter and carcass characteristics of lambs. J. Fac. Vet. Med. Istanbul Univ. $31,75-89$

Ekiz, B., Demirel, G., Yilmaz, A., Ozcan, M., Yalcintan, H., Kocak, O. \& Altinel, A., 2013. Slaughter characteristics, carcass quality and fatty acid composition of lambs under four different production systems. Small Rumin. Res. 114, 26-34.

Ekiz, B., Yilmaz, A., Ozcan, M. \& Kocak, O., 2012. Effect of production system on carcass measurements and meat quality of Kivircik lambs. Meat Sci. 90, 465-471.

Ekiz, B., Yilmaz, A., Ozcan, M., Kaptan, C., Hanoglu, H., Erdogan, I. \& Yalcintan, H., 2009. Carcass measurements and meat quality characteristics of Turkish Merino, Ramlic, Kivircik, Chios and Imroz lambs raised under an intensive production system. Meat Sci. 82, 64-70.

Fisher, A.V., Enser, M., Richardson, R.I., Wood, J.D., Nute, G.R., Kurt, E., Sinclair, L.A. \& Wilkinson RG. 2000. Fatty acid composition and eating quality of lamb types derived from four diverse breed $\times$ production systems. Meat Sci. 55, 141-147.

Hoffman, L.C., Muller, M., Cloete, S.W.P. \& Schmidt, D., 2003. Comparison of six crossbred lamb types: sensory, physical and nutritional meat quality characteristics. Meat Sci. 65, 1265-1274.

Honikel, K., 1998. Reference methods for the assessment of physical characteristics of meat. Meat Sci. 49, 447-457.

Hopkins, D.L. \& Fogarty, N.M., 1998. Diverse lamb genotypes-2. Meat pH, colour and tenderness. Meat Sci. 49, 477488.

Hopkins, D.L. \& Nicholson, A., 1999. Meat quality of wether lambs grazed on either saltbush (Atriplex nummularia) plus supplements or lucerne (Medicago sativa). Meat Sci. 51, 91-95.

Horcada, A., Beriain, M.J., Purroy, A., Lizaso, G. \& Chasco, J., 1998. Effect of sex on meat quality of Spanish lamb breeds (Lacha and Rasa Aragonesa). Anim. Sci. 67, 541-547.

Karabacak, A., 2007. Fattening performance and carcass characteristics of some fat tailed and thin tailed sheep breeds. PhD thesis, Selcuk University, Turkey (in Turkish, English abstract).

Karabacak, A. \& Boztepe, S., 2008. Slaughter and carcass characteristics of some fat tailed and thin tailed native sheep. J. Selcuk Univ. Agr. Fac. 22, 74-81.

Khliji, S., Van de Ven, R., Lamb, T.A., Lanza, M. \& Hopkins, D.L., 2010. Relationship between consumer ranking of lamb colour and objective measures of colour. Meat Sci. 85, 224-229.

Koусu, E. \& Ozder, M., 2004. Fattening performance, slaughter and carcass characteristics of Turkgeldi twin lambs. J. Anim. Prod. 45, 33-38.

Linares, M.B., Bórnez, R. \& Vergara, H., 2007. Effect of different stunning systems on meat quality of light lamb. Meat Sci. 76, 675-681.

Martínez-Cerezo, S., Sañudo, C., Panea, B., Medel, I., Delfa, R., Sierra, I., Beltrán, J.A., Cepero, R. \& Olleta, J.L., 2005. Breed, slaughter weight and ageing time effects on physico-chemical characteristics of lamb meat. Meat Sci. 69, 325-333.

Morbidini, L, Sarti, D.M., Pollidori, P. \& Valigi, V., 2001. Carcass, meat and fat quality in Italian Merino derived lambs obtained with "organic" farming systems. CIHEAM Options Meditérranéennes 46, 29-33.

Murray, A.C., 1995. The evaluation of muscle quality. In: Quality and grading of carcasses of meat animals. CRC Press, London. pp. 83-108.

Ozcan, M., Ekiz, B., Yılmaz, A. \& Ceyhan, A., 2005. Genetic parameter estimates for lamb growth traits and greasy fleece weight at first shearing in Turkish Merino sheep. Small Rumin. Res. 56, 215-222.

Pérez, P., Maino, M., Morales, M.S., Köbrich, C., Bardon, C. \& Pokniak, J., 2007. Gender and slaughter weight effects on carcass quality traits of suckling lambs from four different genotypes. Small Rumin. Res. 70, 124-130.

Polidori, P., Pucciarelli, S., Cammertoni, N., Polzonetti, V. \& Vincenzetti, S., 2017. The effects of slaughter age on carcass and meat quality of Fabrianese lambs. Small Rumin. Res, 155, 12-15.

Ponnampalam, E.N., Hopkins, D.L. \& Bekit, A., 2014. Predicting colour and flavour stabilities of meat from pre-slaughter assessments. Final report. Meat \& Livestock Australia Limited, North Sydney, NSW, Australia. Project Number A.MQA.006.

Priolo, A., Micol, D. \& Agabriel, J., 2001. Effects of grass feeding systems on ruminant meat colour and flavour. A review. Anim. Res. 50, 185-200. 
Purchas, R.W., Silva Sobrino, A.G., Garrick, D.J. \& Lowe, K.I., 2002. Effects of age at slaughter and sire genotype on fatness, muscularity, and the quality of meat from ram lambs born to Romney ewes. New Zeal. J. Agr. Res. 45, 7786.

Ruiz de Huidobro, F., Miguel, E., Onega, E. \& Blazquez, B., 2003. Changes in meat quality characteristics of bovine meat during the first 6 days post mortem. Meat Sci. 65, 1439-1446.

Santos, V.A.C., Silva, S.R., Mena, E.G. \& Azevedo, J.M.T., 2007. Live weight and sex effects on carcass and meat quality of 'Borrego Terrincho-PDO' suckling lambs. Meat Sci. 77, 654-661.

Santos, V.A.C., Cabo, A., Raposo, P., Silva, J.A., Azavedo, J.M.T. \& Silva, S.R., 2015. The effect of carcass weight and sex on carcass composition and meat quality of 'Cordeiro Mirandês' - Protected designation of origin lambs. Small Rumin. Res, 130, 136-410.

Santos-Silva, J. \& Portugal, A.V., 2001. The effect of weight on carcass and meat quality of Serra da Estrela and Merino Branco lambs fattened with dehydrated lucerne. Anim. Res. 50, 289-298.

Sañudo, C., Sierra, I., Olletta, J.L., Martin, L., Campo, M.M., Santolaria, P., Wood, J.D. \& Nute, G.R., 1998. Influence of weaning on carcass quality, fatty acid composition and meat quality in intensive lamb production systems. Anim. Sci. 66, 175-187.

Sezenler, T., Soysal, D., Yildirir, M., Yuksel, M.A., Ceyhan, A., Yaman, Y., Erdogan, I. \& Karadag, O., 2013. Influence of some environmental factors on litter size and lamb growth performance in Karacabey Merino sheep. JOTAF 10, 40-47.

Shackelford, S.D., Morgan, J.B., Cross, H.R. \& Savell, J.W., 1991. Identification of threshold levels for Warner-Bratzler shear force in beef top loin steaks. J. Muscle Foods 2, 289-296.

Silva Sobrinho, A.G., Kadim, I.T. \& Purchas, R.W., 2003. Effect of genotypes and age on carcass and meat quality characteristics of ram lambs. JAMS 8, 73-78.

Teixeira, A., Batista, S., Delfa, R. \& Cadavez, V., 2005. Lamb meat quality of two breeds with protected origin designation. Influence of breed, sex and live weight. Meat Sci. 71, 530-536.

Tejeda, J.F., Peña, R.E. \& Andrés, A.I., 2008. Effect of live weight and sex on physico-chemical and sensorial characteristics of Merino lamb meat. Meat Sci. 80, 1061-1067.

Thompson, J.M., Atkins, K.D. \& Gilmour, A.R., 1979. Carcass characteristics of heavy weight crossbred lambs. II. Carcass composition and partitioning of fat. Aust. J. Agric. Res. 30, 1207-1214.

Velasco, S., Lauzurica, S., Caneque, V., Perez, C., Huidobro, F., Manzanares, C. \& Díaz, M.T., 2000. Carcass and meat quality of Talaverana breed sucking lambs in relation to gender and slaughter weight. Anim. Sci. 70, 253-263.

Warner, R.D., Pethick, D.W., Greenwood, P.L., Ponnampalam, E.N., Banks, R.G. \& Hopkins, D.L., 2007. Unravelling the complex interactions between genetics, animal age and nutrition as they impact on tissue deposition, muscle characteristics and quality of Australian sheep meat. Anim. Prod. Sci. 47, 1229-1238.

Yalcin, B.C., 1986. Sheep and goats in Turkey. FAO Animal Production and Health Paper, No 60. FAO, Rome.

Yilmaz, A., Ekiz, B., Ozcan, M., Kaptan, C., Hanoglu, H., Erdogan, I. \& Kocak, O., 2009. Carcass quality characteristics of improved and indigenous lamb breeds of North-Western Turkey under an intensive production system. Ital. J. Anim. Sci. 8, 663-675.

Yilmaz, A., Ozcan, M., Ekiz, B. \& Akgunduz, M., 2002. Investigations on the possibility of improving the meat production by crossbreeding Turkish Merino, Chios and Kivircik sheep breeds-2. Fattening, slaughter and carcass characteristics of lambs. Turk. J. Vet. Anim. Sci. 26, 1333-1340. 